\title{
Chicory Leave Powder as A Functional Ingredient: Chemical Composition, Bioactive Compounds and Antioxidant Activity
}

\author{
Hamid M. Ziena, Soad T. Kheir and Basma R. Ghazie ${ }^{1}$
}

\begin{abstract}
In this research, the chemical composition, bioactive compounds and antioxidant activity were estimated in chicory leave powder. The results of those analyses were needed to check the functional properties of the powder. The chemical composition result of leave powder was as respectively; moisture content $(6.79 \%)$, crude protein $(\mathbf{1 5 . 0 2} \%)$, crude fiber $(16.46 \%)$, ash $(10.80 \%)$, fat $(3.90 \%)$ and nitrogen-free extract $(53.82 \%)$. Amino acids, fatty acids and mineral content were also evaluated. The bioactive compounds analysis of the leave powder showed that the amount of total flavonoids and total phenols as respectively $(8.50 \mathrm{mg} / \mathrm{g})$ and $(26.4 \mathrm{mg} / \mathrm{g})$. The powder was found to contain a high amount of mineral elements such as $\mathrm{Ca}$ (the highest), $\mathrm{K}, \mathrm{Mg}, \mathrm{Na}$ and $\mathrm{Mn}$ (the lowest). Amino acid analysis showed that glutamic acid is the dominant amino acid and cysteine represents the lowest value. According to the result of amino acids, chicory leave powder is characterized by containing higher levels of some amino acids than the FAO/WHO pattern. Those amino acids were leucine, valine and threonine respectively. As a result of fatty acids analysis, the leaves powder was found to contain a high value of linoleic acid (C18:2) while behenic acid (C22:0) represents the lowest value. The antioxidant activity value of the powder showed 45.5\% DPPH inhibition. All this make chicory leave powder a good candidate in functional foods.
\end{abstract}

Keywords: Chicory, Chemical composition, Total flavonoids content, Total phenolic compounds, Antioxidant activity.

\section{INTRODUCTION}

Chicory (Cichorium intybus L.), a perennial herb of the Asteraceae family is native to the Mediterranean region, mid-Asia and northern Africa. Historically, chicory was grown by the ancient Egyptians as they believed that chicory is a good medicinal plant and used it in several folk treatments (Centeno,2004). In Egypt, people eat fresh leaves of chicory and sometimes use it in salads and the leaves of several Cichorium species have been used for centuries as part of the traditional diet in the Mediterranean countries (as salads or cooked vegetables, and in meat dishes), while the roots are baked, ground, and used as a substitute for coffee and inulin source. The bitter taste of chicory leaves is highly appreciated in some Mediterranean cuisine (in Italy, Spain, Greece and Turkey) Jancic et al., (2017). Leaves of chicory are a good source of phenols as well as potassium, calcium, and phosphorus. Chicory has been traditionally used for the treatment of fever, diarrhea, jaundice and gallstones Abbas et al., (2014). The studies on rats have shown that chicory possesses antihepatotoxic and anti-diabetic activities Saggu et al., (2014). It has been also reported that chicory possesses anti-bacterial (Nandagopal and Ranjitha Kumari ,2007), anti-inflammatory (Cavin et al.,2005), hyperglycaemic and anti-ulcerogenic activities Uz-Zaman et al.,(2006).

Due to good chemical composition, bioactive compounds and antioxidant activity of chicory leaves, it would be a valuable candidate in the functional food industry and can play an important role in improving human health by participating in the antioxidant defense system against endogenous free radicals. The objective of this study was to evaluate the chemical composition, bioactive compounds and antioxidant activity of chicory leave powder as a new source for functional foods production.

\section{MATERIALS AND METHODS}

\section{Materials:}

\section{Collection and preparation of Chicory samples:}

Chicory (Cichorium Intybus L.) leave was collected from a field in Kafr el dawar District, El-Beheira Governorate, and Egypt in March 2021. The leave of the plant was washed with tap water to remove the remaining soil and other impurities then dried for 3 days at room temperature until the leave easy converted into powder. The dried leave was milled by an electric mill and then sifted through a 40 mesh sieve. The sifted samples were put in airtight glass jars. The samples were stored in the refrigerator at $4^{\circ} \mathrm{C}$ until further use.

\section{Chemical composition analysis:}

The recommended methods by the Association of Official Analytical Chemists (AOAC.2000) were used for the determination of moisture, ash, fat, protein and crude fiber content. While nitrogen-free extract was calculated by difference.

Minerals analysis was determined using atomic absorption spectrophotometry according to AOAC (2000). 
Amino acid analysis of chicory leave powder was determined and estimated according to the method described by AOAC (2000).

Fatty acid analysis: of chicory leave was determined according to the method described by Radwan, (1978).

\section{Total Flavonoids analysis:}

The total flavonoids content were measured by the method described by Shad et al., (2013). The total flavonoids content of the extract was expressed as $\mathrm{mg}$ catechin equivalents (CE) per gram of sample $(\mathrm{mg} / \mathrm{g})$ and calculated from the calibration curve. HPLC was used for the fractionation and determination of the total flavonoids using the method outlined by Goupy et al., (1999), and Mattila et al., (2000).

\section{Total phenolic analysis:}

The content of phenolics was expressed as gallic acid equivalent in $\mathrm{mg} / \mathrm{g}$. HPLC was used for the analysis of methanolic extract and to identify the phenolic compounds exactly according to Goupy et al., (1999), and Mattila et al., (2000).

\section{Antioxidant activity, the DPPH:}

The DPPH scavenging activity was measured by the method reported by (Hatano et al., 1988) and the absorbance was assayed at $517 \mathrm{~nm}$. Percent inhibition was calculated. Ascorbic acid was used as a standard in the DPPH assay.

\section{RESULTS AND DISCUSSION}

\section{Chemical composition:}

The chemical composition of chicory leave powder is shown in Table (1). Moisture, crude protein, crude fiber, ash, fat and nitrogen-free extract were 6.79, 15.02, $16.46,10.80,3.90$ and $53.82 \%$ (on a dry weight basis), respectively. The results presented in this study were found to be in the range of the value reported by Nwafor et al., (2017) and Perović et al., (2021).

Table1. Chemical composition of chicory leave powder

\begin{tabular}{lc}
\hline Chemical composition & \% \\
\hline Moisture & 6.79 \\
Crude protein & 15.02 \\
Crude fiber & 16.46 \\
Ash & 10.80 \\
Fat & 3.90 \\
Nitrogen-free extract & 53.82 \\
\hline
\end{tabular}

\section{Mineral content:}

The results of the mineral content of chicory leave powder revealed that the leave was rich in some the important minerals such as $\mathrm{Ca}, \mathrm{K}, \mathrm{Mg}, \mathrm{Na}, \mathrm{Zn}, \mathrm{Fe}$ and Mn. It's known that the content of minerals in plants is affected by some factors such as growing conditions, soil characteristics, $\mathrm{pH}$, and the presence of organic matter and the ability of plants to selectively accumulate some of these elements. Potential causes of variation in the content of mineral elements include agricultural practices, precipitation and temperature Tuncturk et al., (2018). Those results agree relatively with the results declared by Schittenhelm, (2001).

Table2. Mineral content $\mathrm{mg} / 100 \mathrm{~g}$ of chicory leave powder

\begin{tabular}{lc}
\hline Minerals content & mg /100 g \\
\hline Sodium $(\mathrm{Na})$ & 70.78 \\
Potassium $(\mathrm{K})$ & 185.63 \\
Magnesium $(\mathrm{Mg})$ & 125.53 \\
Calcium $(\mathrm{Ca})$ & 255.47 \\
Manganese $(\mathrm{Mn})$ & 1.05 \\
Iron $(\mathrm{Fe})$ & 8.87 \\
Zinc $(\mathrm{Zn})$ & 1.93 \\
\hline
\end{tabular}

\section{Amino acid composition:}

Amino acids are present in plants, animals and humans and they have an important role in human health maintenance. As in Table (3) results indicated that leucine, valine, phenylalanine and methionine were the major essential amino acids. Concerning the nonessential, the analysis indicated that the glutamic acid $(24.00 \mathrm{~g} / 100 \mathrm{~g})$ dominated the other detected amino acids. However, arginine and aspartic came in the second order. It could be concluded that chicory leave powder which is rich in lysine can be used to complement cereal protein. Those results are relatively close to the data reported by (GU and $\mathrm{Li}, 2012$ ). According to the WHO (1973) recommended pattern for an ideal dietary protein, chicory leave powder is a good source of most essential amino acids. It contains an appreciable concentration of leucine, valine and threonine compared to the FAO/WHO Pattern (Table 3).

\section{Fatty acid composition:}

As shown in Table (4) the results revealed that the oil of chicory leave powder contains significant quantities of the following fatty acids in descending order; linoleic, linolenic, palmitic, stearic, eicosanoic and behenic acid. However, palmitic acid and stearic acid are the most detected fatty acids among the saturated fatty acids. However, unsaturated fatty acids recorded higher levels $59.48 \%$. In the chicory plant, palmitic acid was detected at a very high portion (26.30 $\%)$.This result is an important detail for the chicory plant compared to other oil seeds and plants. These results agree with the results reported by Kam and Kanberoglu, (2019). 
Table3.Amino acid composition in chicory leave powder

\begin{tabular}{|c|c|c|}
\hline Amino acids composition & $\begin{array}{c}\text { Chicory leaves powder } \mathbf{g} / \mathbf{1 0 0 g} \\
\text { protein }\end{array}$ & FAO/WHO Pattern * \\
\hline \multicolumn{3}{|l|}{ Essential amino acids } \\
\hline Leucine & 6.64 & 4.8 \\
\hline Valine & 4.49 & 4.2 \\
\hline Phenylalanine & 4.70 & 5.6 \\
\hline Methionine & 3.82 & 4.2 \\
\hline Lysine & 3.75 & 4.2 \\
\hline Isoleucine & 3.35 & 4.2 \\
\hline Threonine & 3.23 & 2.8 \\
\hline \multicolumn{3}{|l|}{ Non-essential amino acids } \\
\hline Glumatic acid & 24.00 & \\
\hline Arginine & 10.30 & \\
\hline Aspartic acid & 10.30 & \\
\hline Glycine & 6.64 & \\
\hline Alanine & 4.35 & \\
\hline Serine & 3.88 & \\
\hline Proline & 3.50 & \\
\hline Tyrosine & 3.50 & \\
\hline Histidine & 2.35 & \\
\hline Cysteine & 1.20 & \\
\hline Total essential amino acids \% & 32.33 & \\
\hline Total non-essential amino acids \% & 67.67 & \\
\hline E/N \% & 47.8 & \\
\hline \multicolumn{3}{|c|}{$\begin{array}{l}\text { * FAO Pattern 1957: (g/100 g protein), World Health Organization, 1973. Energy and protein requirements. FAO Nutrition Meetings Report Series } \\
\text { No.52. }\end{array}$} \\
\hline \multicolumn{3}{|c|}{ Table4. Fatty acid composition in chicory leave powder } \\
\hline Fatty acids composition & Symbol & $\%$ \\
\hline Palmitic acid & C16:0 & 26.30 \\
\hline Stearic acid & $\mathrm{C} 18: 0$ & 6.50 \\
\hline Eicosanoic acid & $\mathrm{C} 20: 0$ & 4.00 \\
\hline Linolenic acid & C18:3 & 28.50 \\
\hline Behenic acid & $\mathrm{C} 22: 0$ & 2.50 \\
\hline Linoleic acid & $\mathrm{C} 18: 2$ & 30.98 \\
\hline Total saturated fatty acids \% & & 39.3 \\
\hline Total unsaturated fatty acids \% & & 59.48 \\
\hline Sat/Unsaturated \% & & 66 \\
\hline
\end{tabular}

Bioactive compounds of chicory leave powder:

a) Total phenolic compounds:

Phenolic or polyphenols are secondary plant metabolites that are ubiquitously present in plants and their products. Many of them are reported to have high levels of antioxidant activities. Dzharov et al.,(2016). Table (5) displays that the total phenolic content was $26.4 \mathrm{mg} / \mathrm{g}$. The main phenolic compound found in chicory leave powder was E-vanillic acid $(59.89 \mathrm{mg} / \mathrm{g})$ (Table 6). The result of the total phenolic content of chicory leave powder agree with the result reported by
Massoud et al.,(2009) and hence the result of total phenolic compounds ( Table 6) is in agreement with the result reported by Dallar et al., (2014) and Perović et al., (2021).

Table 5. Total phenols, total flavonoids and antioxidant activity of chicory leave powder

\begin{tabular}{lc}
\hline Component & Value \\
\hline Total phenols mg/g & 26.4 \\
Total flavonoids mg/g & 8.50 \\
Antioxidant activity & 45.5 \\
(DPPH inhibition \%) & \\
\hline
\end{tabular}


Table6. Phenolic compounds of chicory leave powder

\begin{tabular}{lc}
\hline Phenolic compounds & mg/g dry matter \\
\hline Gallic acid & 0.36 \\
Catechol & 0.54 \\
Pyrogallol & 4.23 \\
Epicatechin & 5.48 \\
P-OH-benzoic acid & 1.13 \\
Chlorogenic acid & 1.34 \\
Caffeic acid & 0.37 \\
P-Coumaric acid & 0.35 \\
Vanillic acid & 1.71 \\
Ferulic acid & 1.13 \\
Ellagic acid & 1.41 \\
Iso-Ferulic acid & 0.53 \\
Caffeine & 1.13 \\
E-vanillic acid & 59.89 \\
Cinnamic acid & 0.35 \\
Benzoic acid & 3.59 \\
Coumarin & 1.02 \\
Salicylic acid & 3.61 \\
\hline Total & $\mathbf{8 5 . 1}$ \\
compounds & \\
\hline
\end{tabular}

\section{b) Total flavonoids content:}

The flavonoids play an important role in the biological system; they have antioxidant, antimalarial, anti-inflammatory, antiproliferative, cytotoxic, analgesic, sedative, anti-hepatotoxic and hypoglycaemic bioactive properties (Costa et al., 2017). The total aqueous ethanolic flavonoids content of chicory leave powder was $8.50 \mathrm{mg} / \mathrm{g}$ as shown in Table (5). Results in Table (7) showed that rosmarinic and acacetin recorded the highest levels (20.15 and $14.72 \mathrm{mg} / \mathrm{g}$ respectively). Those results are relatively in agreement with the results reported by Abbas et al., (2014) and Ishfaq et al., (2018).

Table7. Total flavonoids content in chicory leave powder

\begin{tabular}{lc}
\hline $\begin{array}{c}\text { Flavonoid compounds } \\
\text { of dried chicory }\end{array}$ & mg $\backslash \mathbf{g}$ dry matter \\
\hline Naringin & 5.31 \\
Acacetin & 14.72 \\
Rutin & 1.89 \\
Rhamnetin & 1.27 \\
Hesperidin & 6.05 \\
Kaempferol & 0.52 \\
Rosmarinic & 20.15 \\
Hispertin & 2.13 \\
Quercitrin & 3.16 \\
Quercetin & 9.34 \\
\hline Total flavonoid \\
compounds
\end{tabular}

\section{DPPH radical scavenging activity:}

The antioxidant activity of chicory plants was the subject of investigation in numerous scientific studies. The analysis revealed that flavonoids and phenols are present in chicory leave powder. It is well known in general that flavonoids and phenols act as highly effective free radical scavenging and as antioxidants. The result of DPPH scavenging activity was $45.5 \%$ inhibition of DPPH as shown in Table (5). This result is lower than the result reported by Khalaf et al., (2018) $(80.95 \pm 0.39 \%)$. Abbas et al., (2014) reported that the IC50 value of chicory leave extract was found to be $67.2 \pm 2.6 \mu \mathrm{g} / \mathrm{ml}$. The result of DPPH radical inhibition $(45.5 \%)$ is close to the results reported by Ishfaq et al., (2018). This value makes chicory a good raw material for healthy food.

\section{CONCLUSIONS}

In a conclusion, the results of the chemical composition and antioxidant activity of chicory leave powder showed that it could be a good source of bioactive compounds like flavonoids and phenolic compounds as well as some important minerals. This makes the plant an important ingredient to add to the functional food industry, where attention is now drawn to it.

\section{REFERENCE}

Abbas, Z. Kh., Sh. Saggu, M.I. Sakeran, N. Zidan, H. Rehman and A.A. Ansari .2014. Phytochemical, antioxidant and mineral composition of hydroalcoholic extract of chicory (Cichorium intybus L.) leaves. Saudi Journal of Biological Sciences. 22: 322-326.

AOAC.2000. AOAC Approved Methods. The Association of Official Analytical Chemists. ${ }^{17}$ th Edition.

Cavin, C., M. Delannoy, A. Malnoe, E. Debefve, A. Touche, D. Courtois and B. Schilter. 2005. Inhibition of the Expression and Activity of Cyclooxygenase-2 by Chicory Extract. Biochem. Biophys. Res. Commun.327 (3): 742749.

Centeno, M. 2004. Spanish medicinal Plants: Cichorium intybus L. Boletin de la Real Sociedad Espanola de Historia Natural. 99: 41-47.

Costa, Ch., A. Tsatsakis, Ch. Mamoulakis, M. Teodoro, G. Briguglio, E. Caruso, D. Tsoukalas, D. Margina and E. Dardiotis. 2017. Current evidence on the effect of dietary polyphenols intake on chronic. Food and Chemical Toxicology. 110:286-299.

Dallar, A and I. Konczak. 2014. Cichorium intybus from Eastern Anatolia: Phenolic Composition, Antioxidant and Enzyme Inhibitory Activities. Industerial Crops and Products:79-85. 
Dzharov, V.V., A.P. Mishrab, M. A. Shariati, M. S. Atanassova and S. Plygun. 2016. Phytochemical Contents In Solid-Liquid Extraction Of Aqueous Alcoholic Extract Of Chicory (Cichorium Intybus L.) Leaves. Foods and Raw Materials. 4(2): 32-37.

Goupy, P., M. Hugues, P. Biovin and M.J. Amiot. 1999. Antioxidant composition and activity of barley (Hordeum vulgar) and malt extracts and isolated phenolic compound. J. Sci. Food Agric. 79: 1625-1634.

GU, W and J. Li. 2012. Chicory seeds: a potential source of nutrition for food and feed. Journal of Animal \& Plant Science. 13(2): 1736-1746.

Ishfaq, S., S.M. Sabir, H. Khurshid, T. Zaman and Z. Ahmad.2018. Antioxidant Activities and Inhibitory Effect of Taraxacum officinale, Cichorium intybus and Letuca sativa on Prooxidant Induced Lipid Peroxidation in Mice. Croatian Journal of Food Science and Technology. 10 (1):16-22.

Jancic, D., V. Todorovic, H. Sircelj, M. Dodevska, B. Beljkas, D. Znidarcic and S. Sobajic. 2017. Biologically Active Compounds and Antioxidant Capacity of Cichorium Intybus L. Leaves from Montenegro. Food Science. 29:627-643.

Kam, N and G.S. Kanberoglu. 2019. Chemical Analysis and Fatty Acid Composition of the Chicory Plants (Cichorium Intybus L.) by GC-MS. Journal of Engineering Technology and Applied Sciences. 4(2): 51-62.

Khalaf, H.A.A., R.M.A. El Saadani, A.I. EL Desouky, M.H. Abdeldaiem and M.E. El Mehy.2018. Antioxidant and antimicrobial activity of gamma irradiated chicory (Cichorium intybus). Annals of Agric. Sci. Moshtohor.56(1), 51 - 60 .

Massoud, M.I., W.A. Amin and A.A. Elgindy. 2009. Chemical and Technological Studies on Chicory (Cichorium Intybus L.) and Its Applications in Some Functional Food. J. Adv. Agric. Res. 14(3), 735-756.

Mattila, P., J. Astola and J. Kumpulainen. 2000. Determination of Flavonoids in Plant Material by HPLC with Diode-Array and Electro-Array Detections. J. Agric. Food Chem. 48: 5841-5843.

Nandagopal, S and B.D. Ranjitha Kumari. 2007. Phytochemical and antibacterial studies of chicory
(Cichorium intybus L.) - a multipurpose medicinal plant. Adv. Biol. Res. 1 (1-2):17-21.

Nwafor, I.Ch., K. Shale and M.Ch. Achilonu. 2017. Chemical Composition and Nutritive Benefits of Chicory (Cichorium intybus) as an Ideal Complementary and/or Alternative Livestock Feed Supplement. Hindawi:1-12.

Perović, J., V.T. Šaponjac, J. Kojić, J. Krulj, D.A. Moreno, C. García-Viguera, M. Bodroža-Solarov and N.Ilić.2021. Chicory (Cichorium intybus L.) as a food ingredient Nutritional composition, bioactivity, safety, and health claims: A review. Food Chemistry.336:1-15.

Radwan, S. S. 1978. Coupling of two dimension thin layer chromatography with gas chromatography for the quantitative analysis of lipids classes and their constituent fatty acids. J. Chrom. Sci.16:538-542.

Uz-Zaman, R., M.Sh. Akhtar and M.Sh. Khan. 2006. In vitro antibacterial screening of Anethum graveolens L. Fruit, Cichorium intybus L. leaf, Plantago ovata L. seed husk and Polygonum viviparum L. root extracts against helicobacter pylori. Int. J. Pharmacol. 2:674-677.

Saggu, Sh., M.I. Sakeran, N. Zidan, E. Tousson, A. Mohan and H. Rehman. 2014. Ameliorating effect of chicory (Chichorium intybus L.) fruit extract against 4-tertoctylphenol induced liver injury and oxidative stress in male rats. Food Chem. Toxicol. 72C:138-146.

Schittenhelm, S. 2001. Effect of sowing date on the performance root chicory. Eur. J. Agron., 15: 209-220.

Shad, M.A., H. Nawaz, T. Rehman and N. Ikram. 2013. Determination of Some Biochemicals, Phytochemicals and Antioxidant Properties of Different Parts of Cichorium intybus L.: A Comparative Study. The Journal of Animal \& Plant Sciences: 1060-1066.

Hatano, T., H. Kagawa, T. Yasuhara and T. Okuda. 1988. Two New Flavonoids and Other Constituents in Licorice Root; Their Relative Astringency and Radical Scavenging Effects. Chem. Pharm. Bull. 36:2090-2097.

Tuncturk, M., R. Tuncturk, T. Eryigit and L. Nohutçu.2018. Some Chemical Compounds of Cichorium intybus L. Species Distributed in Van Region. Journal of Pharmaceutical Research. 17:83-87.

World Health Organization.1973. Energy and protein requirements. WHO Tech Rep Ser 522:52. 


\section{الملخص العريي}

\section{مسحوق ورق الثيكوريا كمكون وظيفى : التقييم الكيميائي ،المركبات النشطة حيويا والنشاط المضاد}

\section{ل - لاكسدة}

$$
\text { حامد مرسي زينة وسعاد نوفيق خير وبسمة ربيع غازى الهيد }
$$

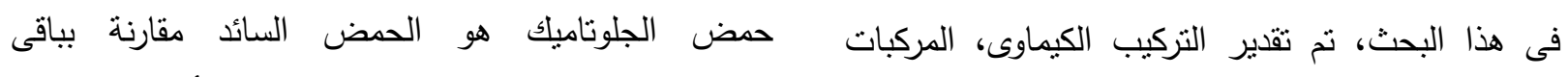

الأحماض وكان حمض السيستين يمثل أقل الأحماض

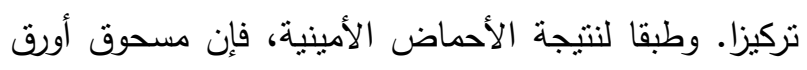

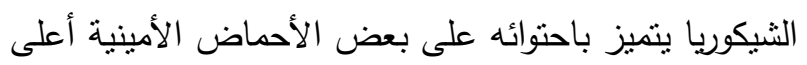

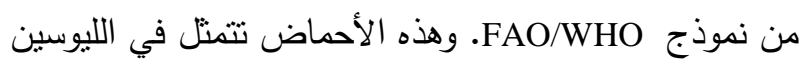

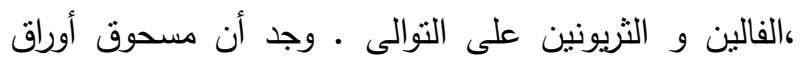
الثيكوريا يحتوى على تركيز عالى من حمض اللينوليك بينما

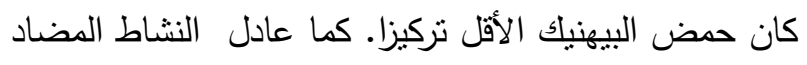

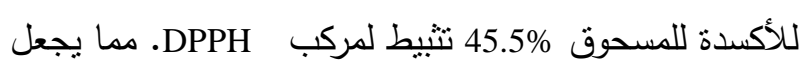

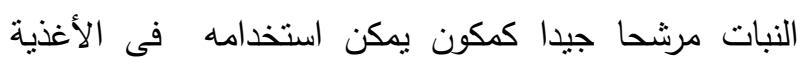

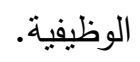

الكلمات المفتاحية: الثيكوريا، التركيب الكيماوي، المحتوى

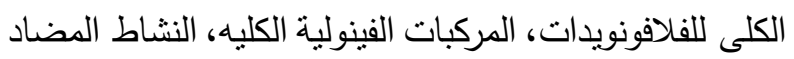
للأكسدة. النشطة حيويا والنشاط المضاد للأكسدة لمسحوق ورق

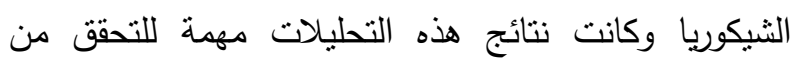
الخصائص الوظيفية لأوراق النبات. كانت نتيجة تحليل

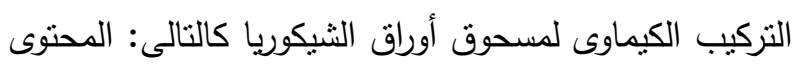

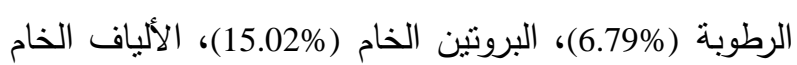

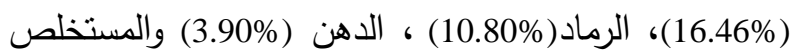

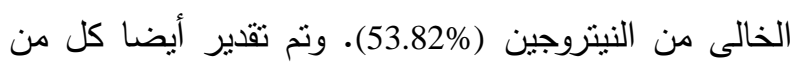
الأحماض الأمينية والدهنية ومحتوى المعادن. أظهر تحليل

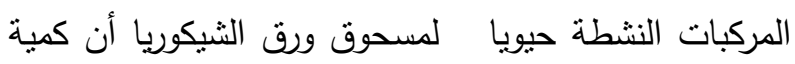

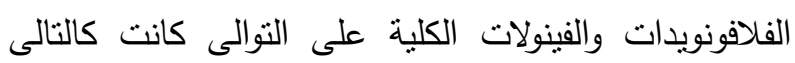

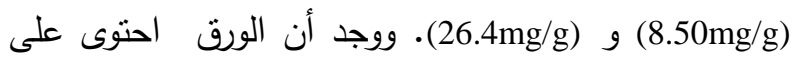

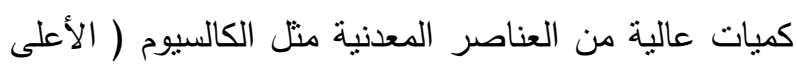
تركيزا ) ، البوتاسيوم ، الماغنسيوم، الصوديوم والمنجنيز (الأقل تركيزا). كما أوضح تحليل الأحماض الأمينية أن النيل 